medRxiv preprint doi: https://doi.org/10.1101/2021.02.24.21251989; this version posted March 5, 2021. The copyright holder for this preprint (which was not certified by peer review) is the author/funder, who has granted medRxiv a license to display the preprint in perpetuity.

It is made available under a CC-BY-NC-ND 4.0 International license .

\title{
Virological and serological characterization of critically ill patients with COVID-19 in the UK: a special focus on variant detection
}

Jeremy Ratcliff $\mathrm{BSc}^{1}$, Dung Nguyen $\mathrm{PhD}^{1}$, Matthew $\mathrm{Fish}^{2}$, Jennifer Rhynne ${ }^{2}$, Aislinn Jennings ${ }^{2}$, Sarah Williams BMBCh${ }^{1}$, Farah Al-Beidh PhD ${ }^{3}$, David Bonsall MD, PhD ${ }^{4,5}$, Amy Evans ${ }^{6}$, Tanya Golubchik PhD ${ }^{5}$, Anthony C Gordon MBBS, MD ${ }^{3,7}$, Abigail Lamikanra PhD ${ }^{8}$, Pat Tsang $\mathrm{MSc}^{8}$, Nick Ciccone PhD ${ }^{8}$, Ullrich Leuscher BSc ${ }^{8}$, Wendy Slack ${ }^{8}$, Emma Laing ${ }^{6}$, Paul R Mouncey $\mathrm{MSc}^{9}$, Sheba Ziyenge MSc ${ }^{8,10}$, Marta Olivera $\mathrm{BSC}^{10,11}$, Rutger Ploeg PhD ${ }^{10,11}$, Kathryn M Rowan PhD ${ }^{9}$, Manu Shankar-Hari MD, PhD ${ }^{2,12}$, David J. Roberts FRCPath, D.Phil ${ }^{8,13}$, David K Menon MD, PhD ${ }^{14}$, Lise Estcourt MBBCh, PhD ${ }^{6,13}$, Peter Simmonds MD, PhD

$$
{ }^{1 \#} \& \text { Heli Harvala MD, } \mathrm{PhD}^{15}{ }^{1 *}
$$

on behalf of the REMAP-CAP Immunoglobulin Domain UK Investigators (listed in the Supp. Appendix).

${ }^{1}$ Nuffield Department of Medicine, Peter Medawar Building for Pathogen Research, University of Oxford, UK;

${ }^{2}$ School of Immunology \& Microbial Sciences, Kings College London, UK;

${ }^{3}$ Imperial College London, London, UK;

${ }^{4}$ Big Data Institute, Li Ka Shing Centre for Health Information and Discovery, Nuffield Department of Medicine, University of Oxford, Oxford, UK;

${ }^{5}$ Wellcome Centre for Human Genetics, University of Oxford, Oxford, UK;

${ }^{6}$ Clinical Trials Unit, NHS Blood and Transplant, Oxford, UK;

${ }^{7}$ Imperial College Healthcare NHS Trust, St. Mary's Hospital, London, UK;

${ }^{8}$ Clinical, Research and Development, NHS Blood and Transplant, Oxford, UK;

${ }^{9}$ Intensive Care National Audit \& Research Centre (ICNARC), London, UK;

${ }^{10}$ Nuffield Department of Surgical Sciences and BRC Surgical Theme, University of Oxford, UK;

${ }^{11} \mathrm{NHS}$ Blood and Transplant Research Laboratory, Oxford, UK;

${ }^{12}$ Guy's and St Thomas' NHS Foundation Trust, St Thomas' Hospital, London, UK;

${ }^{13}$ Radcliffe Department of Medicine and BRC Haematology Theme, University of Oxford, John Radcliffe Hospital, Oxford, UK;

${ }^{14}$ University Division of Anaesthesia, University of Cambridge, Addenbrooke's Hospital Cambridge, Cambridge, UK;

${ }^{15}$ Microbiology Services, NHS Blood and Transplant, London, UK.

\# shared last authors

*To whom correspondence should be addressed.

Tel. +447747096974

Email: Heli.HarvalaSimmonds@nhsbt.nhs.uk

Key words: SARS-CoV-2 COVID-19 Coronavirus Polymerase Chain Reaction

Diagnostics Variant of Concern Clade B.1.1.7

Abstract: $\quad 297$ words

Main text: $\quad 3171$ words 
medRxiv preprint doi: https://doi.org/10.1101/2021.02.24.21251989; this version posted March 5, 2021. The copyright holder for this preprint (which was not certified by peer review) is the author/funder, who has granted medRxiv a license to display the preprint in perpetuity.

It is made available under a CC-BY-NC-ND 4.0 International license .

\section{ABSTRACT}

Background. Treatment of COVID-19 patients with convalescent plasma containing neutralising antibody to SARS-CoV-2 is under investigation as a means of reducing viral loads, ameliorating disease outcomes, and reducing mortality. However, its efficacy might be reduced in those infected with the emerging B.1.1.7 SARS-CoV-2 variant. Here, we report the diverse virological characteristics of UK patients enrolled in the Immunoglobulin Domain of the REMAP-CAP randomised controlled trial.

Methods. SARS-CoV-2 viral RNA was detected and quantified by real-time PCR in nasopharyngeal swabs obtained from study subjects within 48 hours of admission to intensive care unit. Antibody status was determined by spike-protein ELISA. B.1.1.7 strain was differentiated from other SARS-CoV-2 strains by two novel typing methods detecting the B.1.1.7-associated D1118H mutation with allele-specific probes and by restriction site polymorphism $(S f c l)$.

Findings. Of 1260 subjects, 90\% were PCR-positive with viral loads in nasopharyngeal swabs ranging from 72 international units [IUs] $/ \mathrm{ml}$ to $1.7 \times 10^{11} \mathrm{IU} / \mathrm{ml}$. Median viral loads were 45 -fold higher in those who were seronegative for IgG antibodies ( $n=314 ; 28 \%)$ compared to seropositives $(n=804 ; 72 \%)$, reflecting in part the latter group's possible later disease stage on enrolment. Frequencies of B.1.1.7 infection increased from early November (<1\%) to December 2020 (>60\%). Anti-SARS-CoV-2 seronegative individuals infected with wild-type SARS-CoV-2 had significantly higher viral loads than seropositives (medians of $1.2 \times 10^{6}$ and $3.4 \times 10^{4} \mathrm{IU} / \mathrm{ml}$ respectively; $p=2 \times 10^{-9}$ ). However, viral load distributions were elevated in both seropositive and seronegative subjects infected with B.1.1.7 $\left(13.4 \times 10^{6}\right.$ and $\left.7.6 \times 10^{6} \mathrm{IU} / \mathrm{ml} ; p=0.18\right)$.

Interpretation. High viral loads in seropositive B.1.1.7-infected subjects are consistent with increased replication capacity and/or less effective clearance by innate or adaptive immune response of B.1.1.7 strain than wild-type. As viral genotype was associated with diverse virological and immunological phenotypes, metrics of viral load, antibody status and infecting strain should be used to define subgroups for analysis of treatment efficacy. 
medRxiv preprint doi: https://doi.org/10.1101/2021.02.24.21251989; this version posted March 5, 2021. The copyright holder for this preprint (which was not certified by peer review) is the author/funder, who has granted medRxiv a license to display the preprint in perpetuity. It is made available under a CC-BY-NC-ND 4.0 International license .

\section{INTRODUCTION}

The catastrophic zoonotic emergence of severe acute respiratory syndrome coronavirus 2 (SARS-CoV-2) in the human population in China at the end of 2019, and its subsequent pandemic spread has caused global devastation. By the end of January 2021, over 100 million infections and over 2 million COVID-19associated deaths have been reported worldwide To date, only limited treatment regimens exist for COVID-19 patients ${ }^{1,2}$, and their management is primarily supportive, with case-fatality rates remaining at $1 \%-2 \%$ in Western countries including the $\mathrm{UK}^{3}$. In the search of alternative methods to treat COVID-19, convalescent plasma therapy boosting levels of neutralising antibody has been considered as a potential means to reduce morbidity and mortality ${ }^{4,5}$, particularly if given in early stages of infection ${ }^{6}$. RECOVERY and REMAP-CAP are randomized controlled trials investigating the efficacy of convalescent plasma therapy conducted in the UK with REMAP-CAP also recruiting participants globally, ${ }^{6,7}$ In the REMAP-CAP trial $^{7}$ patients with severe COVID-19, restricted to those in intensive care units (ICUs), are transfused with one to two plasma units collected from donors with previous documented SARS-CoV-2 infection and confirmed to have high plasma titres of neutralising antibody $(>1: 100$ based on in vitro live virus neutralisation assays) using surrogate testing with a spike antigen-based ELISA ${ }^{8}$.

While final statistical analysis is awaited, both trials have been paused as an initial analysis did not show a significant benefit of treatment across the overall study population in terms of either COVID-19 associated mortality or number of organ-support free days ${ }^{9,10}$. However, analysis of the data will need to account for patient variables that may influence treatment efficacy, and address patient outcomes other than death. For example, the potential efficacy of convalescent plasma therapy may be influenced by disease stage at trial enrolment. Severe COVID-19 disease may be driven by either the direct effects of virus replication in the respiratory tract, or secondarily from damage associated with the often intense inflammatory antiviral response that usually leads to clearance of SARS-CoV-2. Treatment with neutralising antibody may primarily influence outcomes during the early stages of active virus replication-induced disease but could be less relevant in those patients who have cleared their infection and seroconverted for anti-SARS-CoV-2 antibody. Therefore, we have determined the pre-treatment viral loads in respiratory samples and serological status to categorise study subjects by their disease stage. 
medRxiv preprint doi: https://doi.org/10.1101/2021.02.24.21251989; this version posted March 5, 2021. The copyright holder for this preprint (which was not certified by peer review) is the author/funder, who has granted medRxiv a license to display the preprint in perpetuity.

It is made available under a CC-BY-NC-ND 4.0 International license .

Another variable influencing treatment outcomes may originate from effects of strain variation of SARSCoV-2. A variant of SARS-CoV-2 with a D614G mutation in the spike protein has been described ${ }^{11,12}$ along with more recent mutants such as B.1.1.7 in the UK, B.1.351 in South Africa and B.1.1.28 in Brazil ${ }^{13}$, all potentially more transmissible ${ }^{14}$; furthermore, B.1.1.7 may result in a higher mortality than the original pandemic strain ${ }^{15}$. As regards B.1.351 (South Africa), clustered amino acid changes in the spike protein gene may render this mutant partially antigenically distinct from the prototype $\operatorname{strain}^{16}$. These virological differences, including the possibility of antigenic escape from neutralising antibodies in convalescent plasma collected from individuals with earlier strains of SARS-CoV-2, may individually or collectively affect the efficacy of convalescent plasma therapy. To identify SARS-CoV-2 strains, we developed a realtime PCR targeting the $\mathrm{D} 1118 \mathrm{H}$ polymorphism in the spike gene that is characteristic of the B.1.1.7 strain. This provided a rapid means to differentiate B.1.1.7 from other SARS-CoV-2 strains; in addition, the assay was found to be more effective than high throughput sequencing for low viral load samples. A simpler agarose gel-based method was also developed and evaluated to enable B.1.1.7 identification in resource-limited settings.

Using these methods, we report substantial variability in pre-treatment viral loads, variability in serological status and an increasing detection of B.1.1.7 during the enrolment period of UK participants in the international REMAP-CAP trial ${ }^{7}$. Measurement of these variables will be of considerable value in analysing effects of convalescent plasma therapy and potentially identifying sub-groups of patients for whom this treatment may be effective.

\section{MATERIALS AND METHODS}

Patient Recruitment and Sample Collection. All subjects were enrolled in the UK and had a laboratory confirmed diagnosis of SARS-CoV-2 infection with concomitant severe pneumonia requiring ICU admission. Patients were not eligible if more than 48 hours had elapsed since their ICU admission, if they had already received treatment with any other non-trial prescribed antibody therapy (monoclonal antibody, hyperimmune immunoglobulin, or convalescent plasma) or if more than 14 days had elapsed since hospital admission. A total of 122 hospitals have recruited patients in this trial in the UK (Table S1; Suppl. Data) ${ }^{17}$. Nasopharyngeal or oropharyngeal swabs and serum samples for baseline virological testing were collected from patients prior to the enrolment and frozen at $-80^{\circ} \mathrm{C}$. 
medRxiv preprint doi: https://doi.org/10.1101/2021.02.24.21251989; this version posted March 5, 2021. The copyright holder for this preprint (which was not certified by peer review) is the author/funder, who has granted medRxiv a license to display the preprint in perpetuity. It is made available under a CC-BY-NC-ND 4.0 International license .

Ethical statement. The study was conducted according to the principles of the latest version of the Declaration of Helsinki (version Fortaleza 2013), and in accordance with regulatory and legal requirements (EudraCT number: 2015-002340-14). The study was approved by London-Surrey Borders Research Ethics Committee London Centre (18/LO/0660). Written or verbal informed consent, in accordance with regional legislation, is obtained from all patients or their surrogates.

Nucleic Acid Extraction. Viral RNA was extracted from patient samples using the QIAamp Viral RNA Mini Kit (QIAGEN). $140 \mu \mathrm{L}$ of respiratory sample was mixed with $560 \mu \mathrm{L}$ of Buffer AVL containing $20 \mu \mathrm{g} / \mathrm{mL}$ of linear polyacrylamide (ThermoFisher Scientific), extracted according to the manufacturer's spin protocol, and eluted into $60 \mu \mathrm{L}$ of buffer AVE. Samples that arrived dry were resuspended in $2 \mathrm{~mL}$ of PBS and incubated at room temperature for 20 minutes prior to extraction. NIBSC research reagent 19/304 (https://nibsc.org/products/brm_product_catalogue/detail_page.aspx?catid=20/146) was extracted using the QIAamp Viral RNA Mini Kit and serially diluted in RNA storage solution (Thermo Fisher Scientific; 1] $\mathrm{mM}$ sodium citrate, $\mathrm{pH}$ 6.4) containing herring sperm carrier RNA ( 50 [? $\mu \mathrm{g} / \mathrm{mL}$ ) and RNasin (New England BioLabs UK, 100]U/mL). All samples were subject to a single freeze-thaw cycle between extraction and RT-PCR quantification.

Real-time Polymerase Chain Reaction (PCR). Viral RNA was detected and quantified by real-time polymerase chain reaction (RT-PCR) using the Quantitect Probe RT-PCR kit (QIAGEN) with CDC N1 primers (Table 1; https://www.cdc.gov/coronavirus/2019-ncov/lab/rt-pcr-panel-primer-probes.html) (final concentrations $500 \mathrm{nM}$ for primers and $125 \mathrm{nM}$ for probe (ATDBio)) in $20 \mu \mathrm{L}$ reaction volumes and $5 \mu \mathrm{L}$ of extracted RNA. RT-PCR was carried out on an Applied Biosystems StepOnePlus Real-Time PCR system (ThermoFisher Scientific) with the following settings: $50^{\circ} \mathrm{C}$ for $30 \mathrm{~m}, 95^{\circ} \mathrm{C}$ for $15 \mathrm{~m}$, and 40 cycles of $94^{\circ} \mathrm{C}$ for $15 \mathrm{~s}$ and $60^{\circ} \mathrm{C}$ for $1 \mathrm{~m}$. Intra-assay variation was standardized through use of a standard curve of NIBSC RNA control 19/304 serially diluted from 10,000 copies/reaction to 100 copies/reaction. RTPCR Ct values were converted to copy number/reaction by use of the standard curve and to international units/mL by the conversion rate provided by NIBSC.

Typing assays to identify B.1.1.7 SARS-CoV-2 strains. An RT-PCR using allele-specific probes (ASP) and nested PCR Restriction Fragment Length Polymorphism for the $G \rightarrow C$ polymorphism at position 24814 (D1118H) (Table S1; Suppl. Data) were used to differentiate wild-type and B.1.1.7 strains. Detailed methods are available as Protocols A and B (Suppl. Data). 
medRxiv preprint doi: https://doi.org/10.1101/2021.02.24.21251989; this version posted March 5, 2021. The copyright holder for this preprint (which was not certified by peer review) is the author/funder, who has granted medRxiv a license to display the preprint in perpetuity.

It is made available under a CC-BY-NC-ND 4.0 International license .

Nucleotide sequencing. Whole virus genomes were sequenced using the virus-specific PCR-free sequencing method veSEQ. The full method description is provided in Protocol C (Suppl. Data).

Serology. Baseline blood samples were also collected from all patients to determine the presence of SARS-CoV-2 IgG antibodies against spike protein at the time of transfusion. These were determined using the recently developed and validated 386-well plate ELISA coupled with an automated liquid handler ${ }^{18}$.

\section{RESULTS}

Trial enrolment. Viral loads and anti-SARS-CoV-2 IgG antibody status were determined in respiratory and/or serum samples collected from patients enrolled into REMAP-CAP trial in the UK from $25^{\text {th }}$ May 2020 through $4^{\text {th }}$ January 2021.

Pre-treatment viral loads. RNA extracted from respiratory samples was amplified by real-time PCR using CDC N1 (nucleoprotein gene) primers (Fig. 1A). Ct values were converted to viral loads through coamplification and calibration with the SARS-CoV-2 international reference standard (NIBSC, UK). This placed the assay sensitivity threshold at 100 copies $/ \mathrm{ml}$ for samples with $\mathrm{Ct}$ values $>35$. Using this calibrated assay, a total of 1129 from 1260 samples (89\%) were SARS-CoV-2 RNA positive. Viral loads ranged from $<100 \mathrm{IU} / \mathrm{ml}$ to $1.7 \times 10^{11} \mathrm{IU} / \mathrm{ml}$, a remarkable $>2$ billion-fold range in levels of secreted virus.

Serology. The serological status of each enrolled patient was determined by ELISA to recombinant spike protein. Results were expressed as positive and negative although the degree of antibody reactivity could not be quantified by the nature of the assay. Antibody status has been determined in 1118 patients included in this study to date, of whom 804 were determined as seropositive (72\%). The median viral load of seronegative individuals was $36 \mathrm{x}$ higher than seropositives with markedly different distributions of viral loads between the two groups (Fig. 1A). The proportion of seropositive patients varied systematically with viral load ranges, being highest $(85 \%)$ in those with the lowest viral load $1<$ through to $48 \%$ in those with viral loads $>10^{8} \mathrm{IU} / \mathrm{ml}$ (Fig. 1B).

SARS-CoV-2 strain identification. As infections with the emerging B.1.1.7 strain may respond differently to treatment compared to previously circulating strains of SARS-CoV-2, two different typing assays were 
medRxiv preprint doi: https://doi.org/10.1101/2021.02.24.21251989; this version posted March 5, 2021. The copyright holder for this preprint (which was not certified by peer review) is the author/funder, who has granted medRxiv a license to display the preprint in perpetuity. It is made available under a CC-BY-NC-ND 4.0 International license .

developed to identify B.1.1.7 in trial patients. We first analysed the specificity and predictive value of individual polymorphic sites in the spike gene of B.1.1.7 (H69/V70del., Y144del., N501Y, A570D, P681H, T716I, S982A, D1118H) that differentiated them from other SARS-CoV-2 strains (Table 1). All but one of the defined polymorphisms differentiated B.1.1.7 with very high sensitivity and specificity from previously circulating strains in the UK and from emerging strains in South Africa and Brazil (B.1.351 and B.1.1.28). The exception was the H69/V70 del site which showed increasing frequencies with time in multiple lineages of wild-type strains (Table S2; Suppl. Data). As the $\mathrm{G}->\mathrm{C}$ change associated with $\mathrm{D} 1118 \mathrm{H}$ also led to the loss of a restriction enzyme site $(S f \mathrm{cl})$, amplicons from this region were used in typing assays with allele-specific probes (ASP; Fig. S1A; Suppl. Data) and nested-PCR RFLP assays (Fig. S1B; Suppl. data).

For baseline genomic characterisation, the first 284 respiratory samples collected in November 2020 from the trial patents were sequenced by HTS using SARS-CoV-2-baited target enrichment. Variable coverage of the genome was achieved, associated with viral load (Fig. S2; Suppl. Data). All sequences with coverage over codon 164 of the spike gene showed the D614G mutation. Phylogenetic analysis (Fig. S3; Suppl. Data) of those samples showing $>65 \%$ sequence coverage demonstrated that the majority fell into the lineage GV (according to its designation in GISAID). Of the sequences obtained, 13 of the 173 sequences with sufficient sequence in the spike gene to enable assignment were identifiable as B.1.1.7. No sequences corresponded to emerging strains B.1.351 (South Africa) or B.1.1.28 (Brazil).

A subset of 40 samples sequenced across the spike gene were used for evaluation of the typing assays. These produced highly concordant results with $100 \%$ specificity, $97.5 \%$ sensitivity for the ASP assay, and 97.5\% specificity, 93.5\% sensitivity for the RFLP assay (Table S3; Suppl. Data). Study samples were typed by a combination of the three methods with 521 (400 WT; 121 B.1.1.7) from 645 from tested (81\%) successfully typed.

Emergence and virological associations of SARS-CoV-2 strains. Infections with the B.1.1.7 strain were first detected among enrolled patients in early November and rapidly increased in frequency through November and December, representing over two thirds of infections in the week beginning $21^{\text {st }}$ December 2020 (Fig. 2). Frequencies of B.1.1.7 infections matched their emergence in the general UK population based on analysis of SARS-CoV-2 sequences deposited on GISAID in the corresponding study weeks, albeit at a 1.5-2-fold consistently greater frequency. Geographically, B.1.1.7 infections occurred 
medRxiv preprint doi: https://doi.org/10.1101/2021.02.24.21251989; this version posted March 5, 2021. The copyright holder for this preprint (which was not certified by peer review) is the author/funder, who has granted medRxiv a license to display the preprint in perpetuity.

It is made available under a CC-BY-NC-ND 4.0 International license .

at greatest frequency in subjects enrolled in South East England (including London) and in East England (approximately 50\%; Fig. 3). Cohort enrolment from different regions of England closely matched the proportions of COVID-19 diagnoses reported to PHE over the study period.

Viral loads ranges from subjects infected with the B.1.1.7 strain differed substantially from those with wild-type SARS-CoV-2, with medians of $10,146,774$ and $820,689 \mathrm{IU} / \mathrm{ml}$ respectively $\left(p=2 \times 10^{-9}\right)$. Remarkably, significant differences in viral loads were only apparent among subjects who were seropositive for SARS-CoV-2 antibody (Fig. 4), with an approximately 40-fold difference between medians of B.1.1.7 and wild-type infections. Contrastingly, viral loads varied by less than 2-fold between those with B.1.1.7 and wild-type infections in seronegative subjects. Seropositivity had no significant effect on B.1.1.7 viral loads ( $p=0.47)$. Viral load distributions were elevated in both seropositive and seronegative subjects infected with B.1.1.7 $\left(13.4 \times 10^{6}\right.$ and $\left.7.6 \times 10^{6} \mathrm{IU} / \mathrm{ml} ; \mathrm{p}=0.18\right)$.

\section{DISCUSSION}

This is the first study to demonstrate that median viral loads were substantially higher (45-fold) in seronegative COVID-19 patients admitted to the intensive care unit compared to seropositives. This difference was almost entirely due to 40 -fold higher median viral loads in seropositive B.1.1.7-infected subjects compared to seropositive wild type -infected subjects. These data are consistent with different kinetics of viral growth, removal, and seroconversion in B.1.1.7-infection compared to wild-type SARSCoV-2 infection. Our findings suggest that sub-group analysis of therapeutic trials for COVID-19 should examine outcomes not only by viral load and the presence or absence of anti-spike antibody, but also according to viral genotype that may influence the observed treatment efficacy of convalescent plasma.

The motivation for this study was the need to measure virological variables that can influence the efficacy of convalescent plasma therapy, including the emerging new SARS-CoV-2 variants with potentially reduced neutralisation capacity ${ }^{11,16,19}$ and greater pathogenicity ${ }^{15,20}$. Such analyses have been rarely performed in previous or ongoing COVID-19 treatment trials, yet the findings in this severely unwell patient cohort indicate that the studied patients were virologically highly heterogeneous. 
medRxiv preprint doi: https://doi.org/10.1101/2021.02.24.21251989; this version posted March 5, 2021. The copyright holder for this preprint (which was not certified by peer review) is the author/funder, who has granted medRxiv a license to display the preprint in perpetuity. It is made available under a CC-BY-NC-ND 4.0 International license .

Viral loads were determined using quantitative RT-PCR and results calibrated into international units; the use of the NIBSC international standard to express quantitative data using a common standard allows comparison of viral load data obtained in this and independent studies. As previously mentioned, the often reported $\mathrm{Ct}$ values provide only an indirect metric of viral load, differing for example through varying efficiencies of primer/probe combinations ${ }^{21}$, which implies that quantitative results are not directly comparable. Most striking was the observation of an approximately billion-fold variation in SARS-CoV-2 viral loads as evaluated by a sensitive and quantitative real time RT-PCR for the conserved N gene. This range is consistent with previous studies that report transient, high levels of SARS-CoV-2 RNA detection in acute infection in nasopharyngeal samples. However, the predictive value of viral loads for clinical outcomes or treatment response is unclear, with several studies reporting significant ${ }^{22,23}$, minimal ${ }^{24}$ or no ${ }^{25}$ associations with increased severity or mortality from COVID-19.

The extreme range of viral loads we observed is consistent with the kinetics of SARS-CoV-2 secretion in the respiratory tract, where rapid decline following the acute infection stage were observed ${ }^{23,25}$. Indeed, the observation that RNA levels were $<100 \mathrm{IU} / \mathrm{ml}$ in $10 \%$ of subjects on PCR screening (Fig. 1A) despite severe COVID-19 leading to ICU admission suggests that a substantial element in the disease mechanisms of this latter group is inflammatory or cytokine-related, rather than being directly virally induced. The higher frequency of seropositivity for SARS-CoV-2 in subjects who were classed as PCRnegative or showed lower viral loads in those infected with the virus with the wild-type genotype (Fig. 1B) provides further evidence for differences in the timings of severe disease presentations relative to the evolution of SARS-CoV-2 infection. Viral loads and anti-SARS-CoV-2 antibody status may therefore be additionally determined by the timing of ICU admission relative to disease onset rather than just intrinsic variability in virus replication between individuals in those infected with the virus with the wildtype genotype.

Prospectively, evaluation of disease stage by viral load measurements and serological status provides potentially valuable information for patient stratification in treatment selection for COVID-19. Antiviral effect of neutralising antibodies in convalescent plasma may be most appropriately employed for patients in early disease stages where respiratory tract pathology is primarily virus-driven. Conversely, those presenting late post-seroconversion may therefore not be helped by infusion of additional neutralising antibodies where disease mechanisms may primarily derive from inflammation-mediated damage and who may better respond to interventions that modulate host response (corticosteroids, IL- 
medRxiv preprint doi: https://doi.org/10.1101/2021.02.24.21251989; this version posted March 5, 2021. The copyright holder for this preprint (which was not certified by peer review) is the author/funder, who has granted medRxiv a license to display the preprint in perpetuity. It is made available under a CC-BY-NC-ND 4.0 International license .

6 receptor antagonists ${ }^{1,26}$ ). The importance of identifying those at early stages of infection is demonstrated by the efficacy of convalescent plasma given within 3 days from disease onset ${ }^{6}$ whereas no benefit was seen when plasma was used in later stage infections (median 8 days from onset ${ }^{27}$ ).

The effects of mutations in the spike gene on the transmissibility, viral loads, disease severity and potential antigenic variation is currently an area of substantial concern for COVID-19 pandemic management, public health measures and immunisation programmes. SARS-CoV-2 strains in clade B.1.1.7 have become increasingly prevalent in the UK population whilst the REMAP-CAP convalescent plasma trial patients were drawn (Fig. 2). The spike mutations may lead to a reduction in susceptibility to neutralisation by antibodies elicited by infection or immunisation with previously circulating variants of SARS-COV-2 $2^{19,28}$.

The development of practical methods for rapid and large-scale identification of B.1.1.7 strains is therefore of paramount importance for monitoring its spread worldwide, given its greater propensity to transmit ${ }^{14}$ and overcome containment measures put in place for previously circulating strains of SARSCoV-2. The RFLP assay furthermore enables typing to be done with simple laboratory equipment in resource-limited diagnostic facilities without access to HTS or real-time PCR equipment.

The study subjects showed a substantial representation of B.1.1.7 infections, particularly those recruited towards the end of the study period (Fig. 2), mirroring the appearance of this variant in the wider UK population over this period among primarily non-hospitalised individuals. Very recent investigations have provided evidence that B.1.1.7 infections show a 1.7-fold higher hazard of death within 28 day of diagnosis ${ }^{20}$. These findings are consistent with some, but not all, ongoing studies (summarised $\mathrm{in}^{15}$ ), including higher relative case fatality ratios between B.1.1.7 and WT of 1.29-1.36 (Imperial College London) and mortality hazard ratios of 1.7 (PHE) and 1.7 (University of Exeter). In this context, the finding of substantially higher median viral loads in B.1.1.7 infections compared to wild-type in the REMAP-CAP cohort is of substantial mechanistic relevance. The observation that viral loads were higher in B.1.1.7 only in those who had already seroconverted for anti-SARS-CoV-2 antibody (x40-fold; Fig. 4) are consistent with replication capacity and/or a less effective cellular or humoral host immune response to contain B.1.1.7 replication than wild-type. This contrasts with the G614 spike mutant that manifested greater in vitro fitness and replicative capacity compared to wild-type strains with D614 ${ }^{29}$. The further variable that may influence the efficacy of convalescent plasma therapy is antigenic 
medRxiv preprint doi: https://doi.org/10.1101/2021.02.24.21251989; this version posted March 5, 2021. The copyright holder for this preprint (which was not certified by peer review) is the author/funder, who has granted medRxiv a license to display the preprint in perpetuity.

It is made available under a CC-BY-NC-ND 4.0 International license .

variation; the possibility that B.1.1.7-associated amino acid changes in the spike gene may lead to greater resistance to neutralisation is supported by observations of reduced neutralisation susceptibility of B.1.1.7 pseudotypes compared to wild type in some $e^{19}$ although not all ${ }^{30}$ studies.

Virus strain characterisation contributes substantially to the virological characterisation of the REMAPCAP cohort and its association with higher viral loads may potently influence treatment response. While current indications from the REMAP-CAP trial demonstrate no overall effect on the treated cohort compared to untreated controls ${ }^{10}$, data obtained in the current results will form the basis for further analyses of subgroups defined by antibody status, viral load band and by infecting strain. While this analysis is post hoc, findings may identify specific patient groups who will benefit from convalescent plasma and related immunotherapies in the future.

\section{ACKNOWLEDGEMENTS}

Funding: This study was supported by National Institute for Health (UKRIDHSC COVID-19 Rapid Response Rolling Call, "The use of convalescent plasma to treat hospitalised and critically ill patients with COVID-19 disease", Grant Reference Number COV19-RECPLAS), the European Commission (SUPPORT-E \#101015756),the Platform for European Preparedness Against (Re-) emerging Epidemics (PREPARE) consortium, the European Union, FP7-HEALTH-2013-INNOVATION-1 (\#602525), the Rapid European COVID-19 Emergency Research response (RECOVER) consortium by the European Union's Horizon 2020 research and innovation programme (\#101003589), the UK National Institute for Health Research (NIHR) and the NIHR Imperial Biomedical Research Centre. ACG is funded by an NIHR Research Professorship (RP-2015-06-18) and MSH by an NIHR Clinician Scientist Fellowship (CS-2016-16-011). DKM is supported by the NIHR throughout the Cambridge NIHR BRC, and the Addenbrooke's Charitable Trust.

The views expressed in this publication are those of the authors and not necessarily those of the NHS, the National Institute for Health Research or the Department of Health and Social Care.

Support: We are grateful to the NIHR Clinical Research Network (UK) for their support of participant recruitment. We are grateful to the UK Blood Services (NHS Blood and Transplant, Northern Ireland 
medRxiv preprint doi: https://doi.org/10.1101/2021.02.24.21251989; this version posted March 5, 2021. The copyright holder for this preprint (which was not certified by peer review) is the author/funder, who has granted medRxiv a license to display the preprint in perpetuity. It is made available under a CC-BY-NC-ND 4.0 International license.

Blood Transfusion Service, Scottish National Blood Transfusion Service and Welsh Blood Service) for the supply of convalescent plasma in the UK.

\section{CONFLICTS OF INTEREST}

The authors report no conflicts of interest. 
medRxiv preprint doi: https://doi.org/10.1101/2021.02.24.21251989; this version posted March 5, 2021. The copyright holder for this preprint (which was not certified by peer review) is the author/funder, who has granted medRxiv a license to display the preprint in perpetuity.

It is made available under a CC-BY-NC-ND 4.0 International license .

\section{REFERENCES}

1. Angus DC, Derde L, Al-Beidh F, et al. Effect of Hydrocortisone on Mortality and Organ Support in Patients With Severe COVID-19: The REMAP-CAP COVID-19 Corticosteroid Domain Randomized Clinical Trial. Jama 2020; 324(13): 1317-29.

2. Wang Y, Zhang D, Du G, et al. Remdesivir in adults with severe COVID-19: a randomised, doubleblind, placebo-controlled, multicentre trial. Lancet 2020; 395(10236): 1569-78.

3. Harman K, Allen H, Kall M, Dabrera G. Interpretation of COVID-19 case fatality risk measures in England. J Epidemiol Community Health 2021.

4. Duan K, Liu B, Li C, et al. Effectiveness of convalescent plasma therapy in severe COVID-19 patients. Proc Natl Acad Sci U S A 2020; 117(17): 9490-6.

5. Shankar-Hari M, Estcourt L, Harvala H, Roberts D, Menon DK. Convalescent plasma to treat critically ill patients with COVID-19: framing the need for randomised clinical trials. Crit Care 2020; 24(1): 449 .

6. Libster R, Pérez Marc G, Wappner D, et al. Early High-Titer Plasma Therapy to Prevent Severe Covid-19 in Older Adults. N Engl J Med 2021.

7. Angus DC, Berry S, Lewis RJ, et al. The REMAP-CAP (Randomized Embedded Multifactorial Adaptive Platform for Community-acquired Pneumonia) Study. Rationale and Design. Ann Am Thorac Soc 2020; 17(7): 879-91.

8. Harvala H, Mehew J, Robb ML, et al. Convalescent plasma treatment for SARS-CoV-2 infection: analysis of the first 436 donors in England, 22 April to 12 May 2020. Euro surveillance : bulletin Europeen sur les maladies transmissibles = European communicable disease bulletin 2020; 25(28).

9. Statement from the RECOVERY trial chief investigators, 15 January 2021. 2021.

https://www.recoverytrial.net/news/statement-from-the-recovery-trial-chief-investigators-15january-2021-recovery-trial-closes-recruitment-to-convalescent-plasma-treatment-for-patientshospitalised-with-covid-19.

10. O'Hare R. Blood plasma treatment has limited effect for sickest COVID-19 patients. 2021. https://www.imperial.ac.uk/news/211493/blood-plasma-treatment-limited-effect-sickest/.

11. Plante JA, Liu Y, Liu J, et al. Spike mutation D614G alters SARS-CoV-2 fitness and neutralization susceptibility. bioRxiv 2020.

12. Volz E, Hill V, McCrone JT, et al. Evaluating the Effects of SARS-CoV-2 Spike Mutation D614G on Transmissibility and Pathogenicity. Cell 2021; 184(1): 64-75.e11. 
medRxiv preprint doi: https://doi.org/10.1101/2021.02.24.21251989; this version posted March 5, 2021. The copyright holder for this preprint (which was not certified by peer review) is the author/funder, who has granted medRxiv a license to display the preprint in perpetuity.

It is made available under a CC-BY-NC-ND 4.0 International license .

13. Voloch CM, Silva F Rd, de Almeida LGP, et al. Genomic characterization of a novel SARS-CoV-2 lineage from Rio de Janeiro, Brazil. medRxiv 2020: 2020.12.23.20248598.

14. Volz E, Mishra S, Chand M, et al. Transmission of SARS-CoV-2 Lineage B.1.1.7 in England: Insights from linking epidemiological and genetic data. medRxiv 2021: 2020.12.30.20249034.

15. NERVTAG_update_note_on_B.1.1.7_severity. 2021. https://assets.publishing.service.gov.uk/government/uploads/system/uploads/attachment data/ file/961042/S1095 NERVTAG update note on B.1.1.7 severity 20210211.pdf.

16. Wibmer CK, Ayres F, Hermanus T, et al. SARS-CoV-2 501Y.V2 escapes neutralization by South African COVID-19 donor plasma. bioRxiv 2021: 2021.01.18.427166.

17. UK REMAP-CAP Trial. 2020.

https://static1.squarespace.com/static/5cde3c7d9a69340001d79ffe/t/5f5c842bd7bf523730bdda 76/1599898680445/REMAP-CAP+COVID-19+Immunoglobulin+Therapy+DomainSpecific+Appendix+V1.01-+01+June+2020.pdf.

18. Performance characteristics of five immunoassays for SARS-CoV-2: a head-to-head benchmark comparison. The Lancet Infectious diseases 2020; 20(12): 1390-400.

19. Muik A, Wallisch AK, Sänger B, et al. Neutralization of SARS-CoV-2 lineage B.1.1.7 pseudovirus by BNT162b2 vaccine-elicited human sera. Science 2021.

20. Davies NG, Jarvis Cl, Edmunds WJ, Jewell NP, Diaz-Ordaz K, Keogh RH. Increased hazard of death in community-tested cases of SARS-CoV-2 Variant of Concern 202012/01. medRxiv 2021: 2021.02.01.21250959.

21. Dahdouh E, Lázaro-Perona F, Romero-Gómez MP, Mingorance J, García-Rodriguez J. C(t) values from SARS-CoV-2 diagnostic PCR assays should not be used as direct estimates of viral load. The Journal of infection 2020.

22. Zacharioudakis IM, Zervou FN, Prasad PJ, et al. Association of SARS-CoV-2 genomic load trends with clinical status in COVID-19: A retrospective analysis from an academic hospital center in New York City. Plos One 2020; 15(11): e0242399.

23. Lui G, Ling L, Lai CK, et al. Viral dynamics of SARS-CoV-2 across a spectrum of disease severity in COVID-19. The Journal of infection 2020; 81(2): 318-56.

24. Fang Z, Zhang Y, Hang C, Ai J, Li S, Zhang W. Comparisons of viral shedding time of SARS-CoV-2 of different samples in ICU and non-ICU patients. The Journal of infection 2020; 81(1): 147-78.

25. Yilmaz A, Marklund E, Andersson M, et al. Upper Respiratory Tract Levels of Severe Acute Respiratory Syndrome Coronavirus 2 RNA and Duration of Viral RNA Shedding Do Not Differ 
medRxiv preprint doi: https://doi.org/10.1101/2021.02.24.21251989; this version posted March 5, 2021. The copyright holder for this preprint (which was not certified by peer review) is the author/funder, who has granted medRxiv a license to display the preprint in perpetuity. It is made available under a CC-BY-NC-ND 4.0 International license.

Between Patients With Mild and Severe/Critical Coronavirus Disease 2019. J Infect Dis 2021;

223(1): $15-8$.

26. Gordon AC, Mouncey PR, Al-Beidh F, et al. Interleukin-6 Receptor Antagonists in Critically III Patients with Covid-19 - Preliminary report. medRxiv 2021: 2021.01.07.21249390.

27. Simonovich VA, Burgos Pratx LD, Scibona P, et al. A Randomized Trial of Convalescent Plasma in Covid-19 Severe Pneumonia. N Engl J Med 2020.

28. Haynes WA, Kamath K, Lucas C, Shon J, Iwasaki A. Impact of B.1.1.7 variant mutations on antibody recognition of linear SARS-CoV-2 epitopes. medRxiv 2021: 2021.01.06.20248960.

29. Hou YJ, Chiba S, Halfmann P, et al. SARS-CoV-2 D614G variant exhibits efficient replication ex vivo and transmission in vivo. Science 2020; 370(6523): 1464-8.

30. Planas D, Bruel T, Grzelak L, et al. Sensitivity of infectious SARS-CoV-2 B.1.1.7 and B.1.351 variants to neutralizing antibodies. bioRxiv 2021: 2021.02.12.430472. 
medRxiv preprint doi: https://doi.org/10.1101/2021.02.24.21251989; this version posted March 5, 2021. The copyright holder for this preprint (which was not certified by peer review) is the author/funder, who has granted medRxiv a license to display the preprint in perpetuity.

It is made available under a CC-BY-NC-ND 4.0 International license.

TABLE 1

SPECIFICITY AND SENSITVITY OF THE EIGHT POLYMORHISMS IN B.1.1.7 FOR STRAIN IDENTIFICATION

\begin{tabular}{|c|c|c|c|c|c|c|c|c|c|}
\hline \multirow[b]{2}{*}{ Strain } & \multirow[b]{2}{*}{ Source } & \multicolumn{2}{|c|}{ H69/V70 deletion ${ }^{1}$} & \multicolumn{2}{|c|}{ Y144 deletion } & \multicolumn{2}{|c|}{ N501Y } & \multicolumn{2}{|c|}{ A570D } \\
\hline & & WT & Del & WT & Del & A & $\mathbf{U}$ & C & A \\
\hline B.1.1.7 & $\mathrm{UK}^{2}$ & 0 & 26,328 & 0 & 26,328 & 0 & 26,328 & 2 & 26,359 \\
\hline B.1.1.28 & $\mathrm{All}^{3}$ & 374 & 0 & 374 & 0 & 294 & 80 & 374 & 0 \\
\hline B.1.351 & $\mathrm{All}^{4}$ & 834 & 0 & 834 & 0 & 0 & 834 & 833 & 0 \\
\hline WT & $U^{4}$ & 36,577 & 470 & 35,708 & 46 & 36,868 & 177 & 37,597 & 0 \\
\hline \multicolumn{2}{|c|}{ Specificity/Sensitivity ${ }^{5}$} & \multicolumn{2}{|c|}{$98.73 \% / 100 \%$} & \multicolumn{2}{|c|}{$99.87 \% / 100 \%$} & \multicolumn{2}{|c|}{$99.52 \% / 100 \%$} & \multicolumn{2}{|c|}{$99.98 \%$ / 99.99\% } \\
\hline
\end{tabular}

\begin{tabular}{|c|c|c|c|c|c|c|c|c|c|}
\hline \multirow{3}{*}{$\begin{array}{l}\text { Strain } \\
\text { B.1.1.7 }\end{array}$} & \multirow{3}{*}{$\begin{array}{l}\text { Source } \\
\text { UK }\end{array}$} & \multicolumn{2}{|c|}{ P681H } & \multicolumn{2}{|c|}{ T716I } & \multicolumn{2}{|c|}{ S982A } & \multicolumn{2}{|c|}{ D1118H } \\
\hline & & C & A & C & $\mathbf{U}$ & U & $\mathbf{G}$ & G & C \\
\hline & & 0 & 26,351 & 2 & 26,351 & 0 & 26,360 & 0 & 26,358 \\
\hline B.1.1.28 & All & 374 & 0 & 374 & 0 & 374 & 0 & 374 & 0 \\
\hline B.1.351 & All & 832 & 1 & 832 & 1 & 831 & 0 & 834 & 0 \\
\hline WT & UK & 37,442 & 34 & 37,528 & 23 & 37,563 & 0 & 37,579 & 8 \\
\hline \multicolumn{2}{|c|}{ Specificity/Sensitivity } & \multicolumn{2}{|c|}{$99.69 \% / 99.97 \%$} & \multicolumn{2}{|c|}{$99.94 \%$ / 99.99\% } & \multicolumn{2}{|c|}{$100 \% / 100 \%$} & \multicolumn{2}{|c|}{$99.98 \% / 99.97 \%$} \\
\hline
\end{tabular}

${ }^{1}$ For each mutation, mutations associated with B.1.1.7 shown in right hand column

${ }^{2}$ Available sequences from GISAID Nov, Dec, 2020 and Jan, 2021

${ }^{3}$ All available sequence worldwide

${ }^{4}$ Available sequences from GISAID Jan-April, July, Nov, Dec, 2020 and Jan, 2021

${ }^{5}$ Specificity and sensitivity for differentiation B.1.1.7 from WT SARS-CoV-2 sequences 
medRxiv preprint doi: https://doi.org/10.1101/2021.02.24.21251989; this version posted March 5, 2021. The copyright holder for this preprint (which was not certified by peer review) is the author/funder, who has granted medRxiv a license to display the preprint in perpetuity.

COMPARISON OF VIRAL LOADS IN ANTI-SARS-COV-2 SEROPOSITIVE AND SERONEGATIVE SUBJECTS

A)

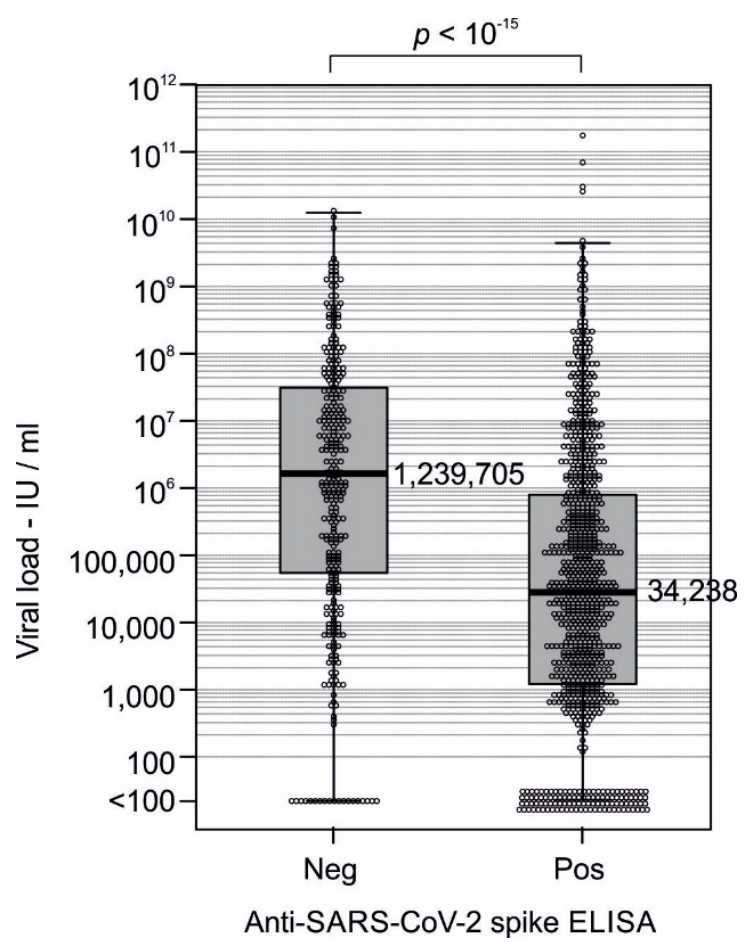

B)

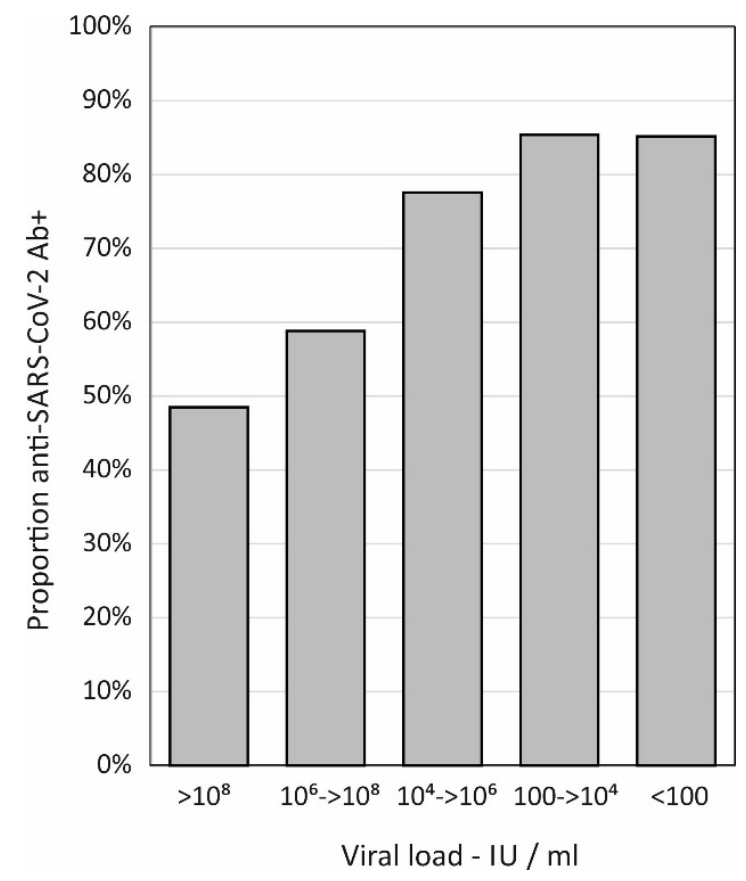

(A) Viral loads of seropositive and seronegative study subjects determined by RT-qPCR of pre-treatment respiratory samples. Median values shown to the right of Tukey box plots. Distributions were compared by Kruskall-Wallis non-parametric test. (B) Frequency of seropositivity in individuals with different viral loads quantified in respiratory samples. 
medRxiv preprint doi: https://doi.org/10.1101/2021.02.24.21251989; this version posted March 5, 2021. The copyright holder for this preprint (which was not certified by peer review) is the author/funder, who has granted medRxiv a license to display the preprint in perpetuity.

It is made available under a CC-BY-NC-ND 4.0 International license .

FIGURE 2

TEMPORAL EMERGENCE OF THE SARS-COV-2 B.1.1.7 CLADE

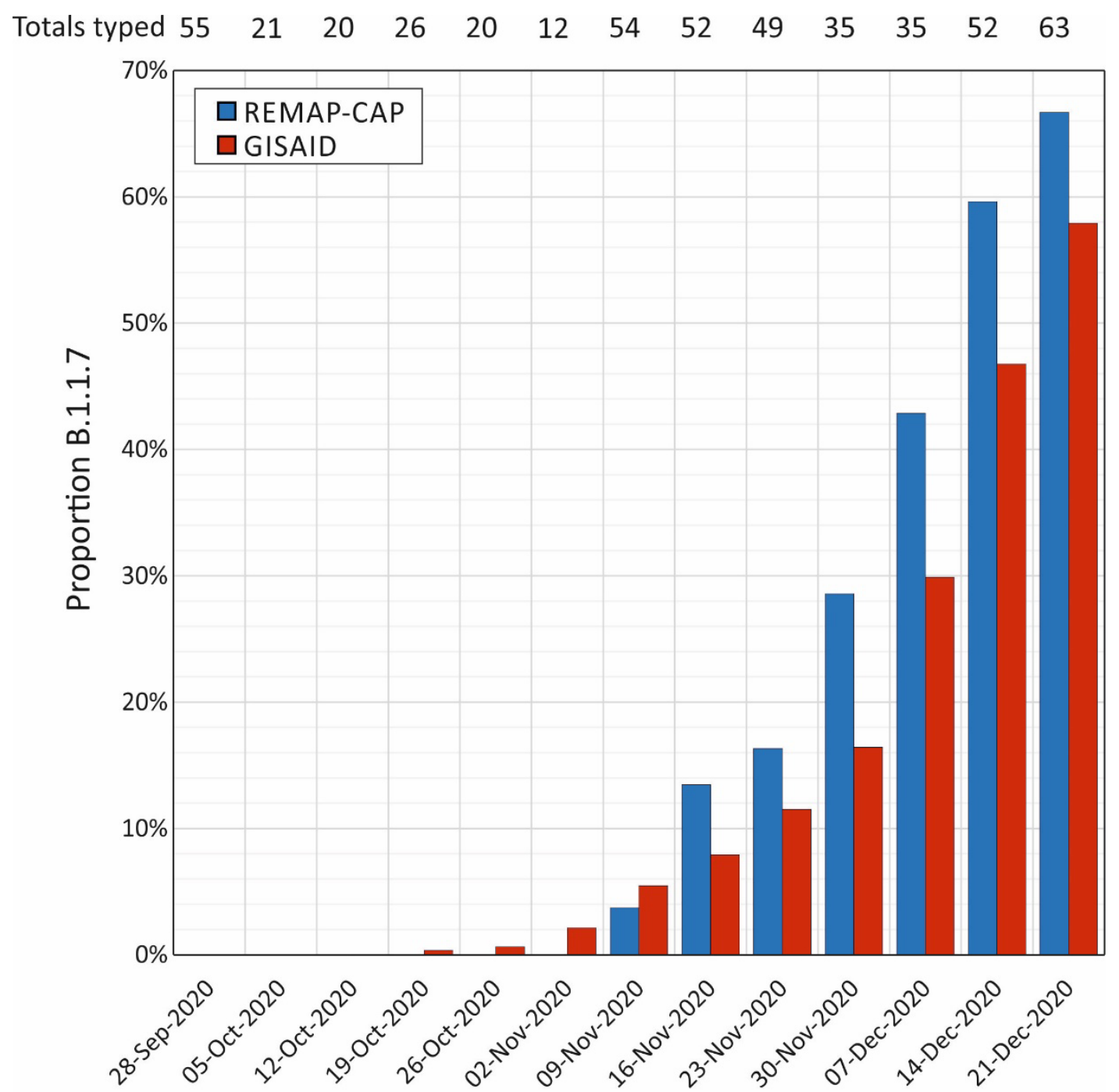

Enrolment week, 2020

Proportion of subjects with the B.1.1.7 clade virus enrolled to the REMAP-CAP trial in different weeks over the study period compared to proportions in the wider UK population from sequences deposited in GISAID. Numbers at the top of the graph indicate total enrolments / week. 
medRxiv preprint doi: https://doi.org/10.1101/2021.02.24.21251989; this version posted March 5, 2021. The copyright holder for this preprint (which was not certified by peer review) is the author/funder, who has granted medRxiv a license to display the preprint in perpetuity.

It is made available under a CC-BY-NC-ND 4.0 International license .

FIGURE 3

REGIONAL REPRESENTATION OF STUDY SUBJECTS AND SARS-COV-2 CASES WITH GENOTYPING DATA AVAILABLE IN ENGLAND

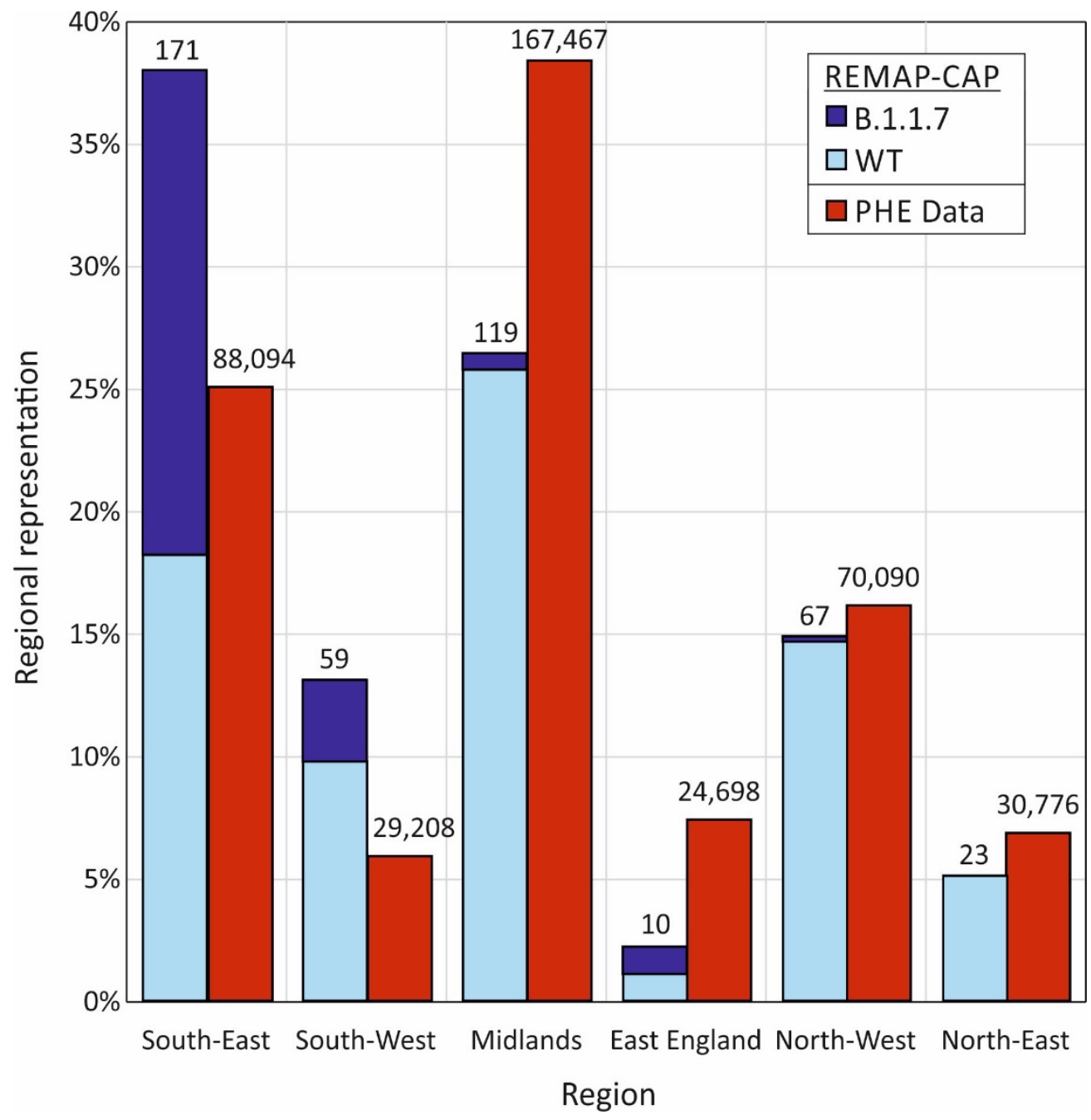

Regional representation of subjects enrolled into the REMAP-CAP trial compared to distributions of SARS-CoV-2 infections proportions in England regions reported to PHE over the study period. Numbers at the top of the graph indicate enrolments numbers / region. 
medRxiv preprint doi: https://doi.org/10.1101/2021.02.24.21251989; this version posted March 5, 2021. The copyright holder for this preprint (which was not certified by peer review) is the author/funder, who has granted medRxiv a license to display the preprint in perpetuity.

It is made available under a CC-BY-NC-ND 4.0 International license .

FIGURE 4

VIRAL LOAD OF WILD-TYPE AND B.1.1.7 STRAINS IN SEROPOSITIVE AND SEROGENATIVE SUBJECTS

Anti-SARS-CoV-2-negative Anti-SARS-CoV-2-positive



Distributions of viral loads of in samples from patients infected with wild-type and B.1.1.7 strains, subdivided by serostatus. Distributions were compared by Kruskall-Wallis non-parametric test. 